UDC 542.943.7; 546.18; 546.562

Zh.K. Kairbekov, D.N. Akbayeva*, Zh.T. Eshova, M.A. Bazhanova

Al-Farabi Kazakh national university, Kazakhstan, Almaty

*E-mail: dnakbayeva@inbox.ru

\title{
Kinetics of the oxidative hydroxylation of sodium hypophosphite in the presence of copper(II) chloride modified by humic (fulvo-) acid
}

\begin{abstract}
It was established that in soft conditions $(50-70 \mathrm{oC}, \mathrm{PO} 2=1 \mathrm{~atm})$ sodium hypophosphite effectively is oxidized by oxygen in water solutions of copper(II) chloride to give mainly a phosphorous acid. Humic (fulvo-) acid was extracted from brown coal of domestic deposit Kiyakty. For determination of optimum parameters of fulvo-acid extraction the laboratory experiments were carried out using the method of experiment planning. The kinetics, the intermediate and final products, optimal conditions of new catalytic reaction of $\mathrm{NaH} 2 \mathrm{PO} 2$ oxidation by oxygen in water solution were defined by kinetics, volumometry, redoxpotentiometry and a titration.

Keywords: sodium hypophosphite, oxidation, oxygen, humic (fulvo-) acid, hydroxylation, phosphorous acid, kinetics, optimum conditions.
\end{abstract}

\section{Introduction}

Despite the big achievements in the field of reactions with participation of hydrophosphoryl compounds (HPC) such as sodium hypophosphite $\left(\mathrm{NaH}_{2} \mathrm{PO}_{2}\right)$, it is necessary to note the absence of researches in such direction, as catalysis by metal complexes. The kinetics and the mechanism, catalytic activity of transition metals complexes $\mathrm{Cu}(\mathrm{II})$, $\mathrm{Fe}(\mathrm{III}), \mathrm{Hg}(\mathrm{II}), \mathrm{Pd}(\mathrm{II}), \mathrm{Ag}(\mathrm{I})$ and the mixed systems on their basis in reactions of an oxidative alkoxylation of phosphorus low-valency compounds $\left(\mathrm{P}_{4}\right.$, $\mathrm{PH}_{3}, \mathrm{Cu}_{3} \mathrm{P}, \mathrm{Zn}_{3} \mathrm{P}_{2}$ ) were studied for the first time by Dorfman Ya.A. with employees [1-5]. However these compounds are toxic reagents. In this regard in present work for the first time in reaction of an oxidative hydroxylation rather harmless sodium hypophosphite was used as the initial phosphorylating agent. To study oxidative hydroxylation of sodium hypophosphite in the presence of metal-complexion catalysts is important for consideration of the general questions of reactive ability of HPC and expansion of possibilities of synthesis of phosphorus-containing compounds.

The purpose of this work is the development of effective catalysts of an oxidative hydroxylation of sodium hypophosphite in the presence of copper(II) chloride modified by humic (fulvo-) acid, obtained from brown coal of domestic deposit Kiyakty.

\section{Materials and methods}

The kinetics of $\mathrm{NaH}_{2} \mathrm{PO}_{2}$ oxidative hydrolysis in water solutions of copper(II) chloride was studied by a volumometric method of oxygen absorption in thermostatic glass reactor of the type "catalytic duck» supplied by the potentiometric device and gasometric burette. The technique of experiment is in detail described in [1]. Sodium hypophosphite and $\mathrm{CuCl}_{2} \cdot 2 \mathrm{H}_{2} \mathrm{O}$ are used without additional cleaning. For determination of optimal parameters of extraction of fulvo-acid (FA) the laboratory experiments were carried out using the method of experiment planning [6]. The matrix of the 4th factorial of experiment plan at the 4th levels was made and optimal conditions of transfer to alkaline solution of fulvo-acid from brown coal of domestic deposit Kiyakty are determined. Optimal conditions of extraction of fulvo-acid: $\mathrm{X}_{1}$ - extraction temperature $-80^{\circ} \mathrm{C} ; \mathrm{X}_{2}$ - duration of experiment $-45 \mathrm{~min}$; $\mathrm{X}_{3}$ - concentration of alkali - $1,0 \% ; \mathrm{X}_{4}$ - ratio of coal and alkali in solution - 1:25. The experiment realized in these conditions was coordinated with sampled data. Determination of phosphorous and humic (fulvo-) acids concentration carried out by acidic-alkaline titration according to a technique given in [7]. 


\section{Results and discussion}

It is found that at oxidation of $\mathrm{NaH}_{2} \mathrm{PO}_{2}$ by oxygen in water solution of copper(II) chloride at 50$70^{\circ} \mathrm{C}$ phosphorous acid is formed:

$$
\mathrm{H}_{2} \mathrm{PO}_{2}^{-}+0,5 \mathrm{O}_{2}+\mathrm{H}_{2} \mathrm{O} \rightarrow \mathrm{H}_{3} \mathrm{PO}_{3}+\mathrm{OH}^{-}
$$

The concentration effect of components of the reactive environment and temperature produced on process velocity (1) is studied. The reaction conditions and products yields of sodium hypophosphite oxidation by oxygen in water solution of $\mathrm{CuCl}_{2}$ are presented in the table.

Table - Oxidation of $\mathrm{NaH}_{2} \mathrm{PO}_{2}$ by oxygen in water solution in the presence of $\mathrm{CuCl}_{2}$ modified by humic (fulvo-) acid

\begin{tabular}{|c|c|c|c|c|c|}
\hline \multicolumn{4}{|c|}{ Composition of solution, $\mathrm{mol} / \mathrm{l}$} & \multirow[t]{2}{*}{$\mathrm{T},{ }^{\circ} \mathrm{C}$} & \multirow{2}{*}{$\begin{array}{r}\text { Yield of } \\
\mathrm{H}_{3} \mathrm{PO}_{3}, \%\end{array}$} \\
\hline$\left[\mathrm{CuCl}_{2} \cdot 2 \mathrm{H}_{2} \mathrm{O}\right]$ & {$\left[\mathrm{NaH}_{2} \mathrm{PO}_{2}\right]$} & {$\left[\mathrm{H}_{2} \mathrm{O}\right]$} & {$[\mathrm{FA}]$} & & \\
\hline 0,28 & 0,34 & 44,4 & 0,06 & 60 & 96 \\
\hline 0,57 & 0,34 & 44,4 & 0,06 & 60 & 93 \\
\hline 1,14 & 0,34 & 44,4 & 0,06 & 60 & 79 \\
\hline 0,57 & 0,34 & 33,3 & 0,11 & 60 & 90 \\
\hline- & 0,34 & - & 0,11 & 60 & 87 \\
\hline- & 0,34 & - & 0,11 & 60 & 65 \\
\hline- & 0,34 & - & 0,11 & 60 & 51 \\
\hline 0,57 & 0,17 & 50,0 & 0,03 & 60 & 92 \\
\hline 0,57 & 0,34 & 50,0 & 0,03 & 60 & 92 \\
\hline 0,57 & 0,68 & 50,0 & 0,03 & 60 & 96 \\
\hline 0,57 & 0,17 & 39,0 & 0,08 & 60 & 85 \\
\hline 0,57 & 0,34 & 39,0 & 0,08 & 60 & 91 \\
\hline 0,57 & 0,68 & 39,0 & 0,08 & 60 & 97 \\
\hline 0,57 & 0,34 & 50,0 & 0,03 & 60 & 87 \\
\hline 0,57 & 0,34 & 39,0 & 0,08 & 60 & 91 \\
\hline 0,57 & 0,34 & 33,3 & 0,11 & 60 & 94 \\
\hline 0,57 & 0,34 & 28,0 & 0,14 & 60 & 93 \\
\hline 0,57 & 0,34 & 50,0 & 0,03 & 50 & 82 \\
\hline 0,57 & 0,34 & 50,0 & 0,03 & 60 & 92 \\
\hline 0,57 & 0,34 & 50,0 & 0,03 & 70 & 96 \\
\hline
\end{tabular}

In the case of absence of catalyst $\mathrm{CuCl}_{2}$ and fulvo-acid the oxidative hydroxylation doesn't proceed and oxygen absorption by water solution of sodium hypophosphite isn't observed. Increase of $\mathrm{CuCl}_{2}$ concentration to $1,14 \mathrm{~mol} / \mathrm{l}$ leads to insignificant decrease in velocity of oxygen absorption. The amount of the absorbed oxygen doesn't depend on $\left[\mathrm{CuCl}_{2}\right]$. The order of reaction found from dependence of $\mathrm{lg}$ $\mathrm{W}_{\max }-\lg \left[\mathrm{CuCl}_{2}\right]$, is close to the first.

Stability of the catalyst is studied by consecutive introduction of sodium hypophosphite in $\mathrm{CuCl}_{2}$-FA$\mathrm{H}_{2} \mathrm{O}-\mathrm{O}_{2}$ solution. Entering of a $\mathrm{NaH}_{2} \mathrm{PO}_{2}$ into light green water solution of $\mathrm{CuCl}_{2}$ in the atmosphere of $\mathrm{O}_{2}$ is accompanied by shift of redox-potential of pair of $\mathrm{Cu}(\mathrm{II}) / \mathrm{Cu}(\mathrm{I})\left(\varphi_{\mathrm{Cu}}\right)$ in the cathodic area from 0,47 to $0,40 \mathrm{~V}$ in within 10 minutes, solution decolouration, formation of a white deposit and the beginning absorption $\mathrm{O}_{2}$. In process of oxygen absorption the potential $\varphi_{\mathrm{Cu}}$ gradually moves in anodic area, the color of solution comes back to the initial. The reaction velocity, insignificant at the beginning of experiment, quickly increases and reaches a maximum point, then gradually reduces to zero. Extreme character of kinetic and conversion curves are in accordance with $\varphi_{\mathrm{Cu}}$ shift on potentiometric curves. It was established that catalytic solution can oxidize till four consecutive portions of $\mathrm{NaH}_{2} \mathrm{PO}_{2}$ without appreciable loss of activity.

Introduction of $\mathrm{NaH}_{2} \mathrm{PO}_{2}$ into light green water solution of $\mathrm{CuCl}_{2}$ in the presence of fulvo-acid extracted from coal of the Kiyakty field at $[\mathrm{FA}]=0,03$ and $0,08 \mathrm{~mol} / \mathrm{l}$ in atmosphere $\mathrm{O}_{2}$ is accompanied by discoloration of solution, formation of a white deposit and beginning of absorption of $\mathrm{O}_{2}$. In process of oxygen absorption color of solution comes back to the initial. The reaction velocity insignificant at the beginning of experience, quickly increases and reaches a maximum point, then gradually reduces to 
zero. At increase in quantity entered into reactionary solution of $\mathrm{NaH}_{2} \mathrm{PO}_{2}$ from 0,17 to $0,68 \mathrm{~mol} / 1$ there is an increase of speed of reaction and amount of the absorbed oxygen in compliance of a stoichiometry of reaction (1).

In the studied conditions the main product of reaction of oxidation of sodium hypophosphite by oxygen in water solutions of copper(II) chloride is phosphorous acid (85-96\%).

The influence of $\mathrm{pH}$ on reaction velocity studied by addition of humic (fulvo-) acid extracted from coal of the Kiyakty field, in the range of concen- tration from 0,03 to $0,17 \mathrm{~mol} / \mathrm{l}$. It is shown (picture below) at increase in concentration of humic (fulvo-) acid to $0,11 \mathrm{~mol} / 1$ the absorption velocity of oxygen grows, but further increase of [FA] to 0,14 $\mathrm{mol} / \mathrm{l}$ slightly reduces the reaction velocity. Extreme nature of dependence of reaction velocity (picture) from concentration of FA is connected with double influence of this additive. On the one hand humic (fulvo-) acid accelerates a hydrolysis of sodium hypophosphite, related to the formation of $\mathrm{OH}^{-}$-ions, according to the equation (1) and by shifting of the balance to the right side.
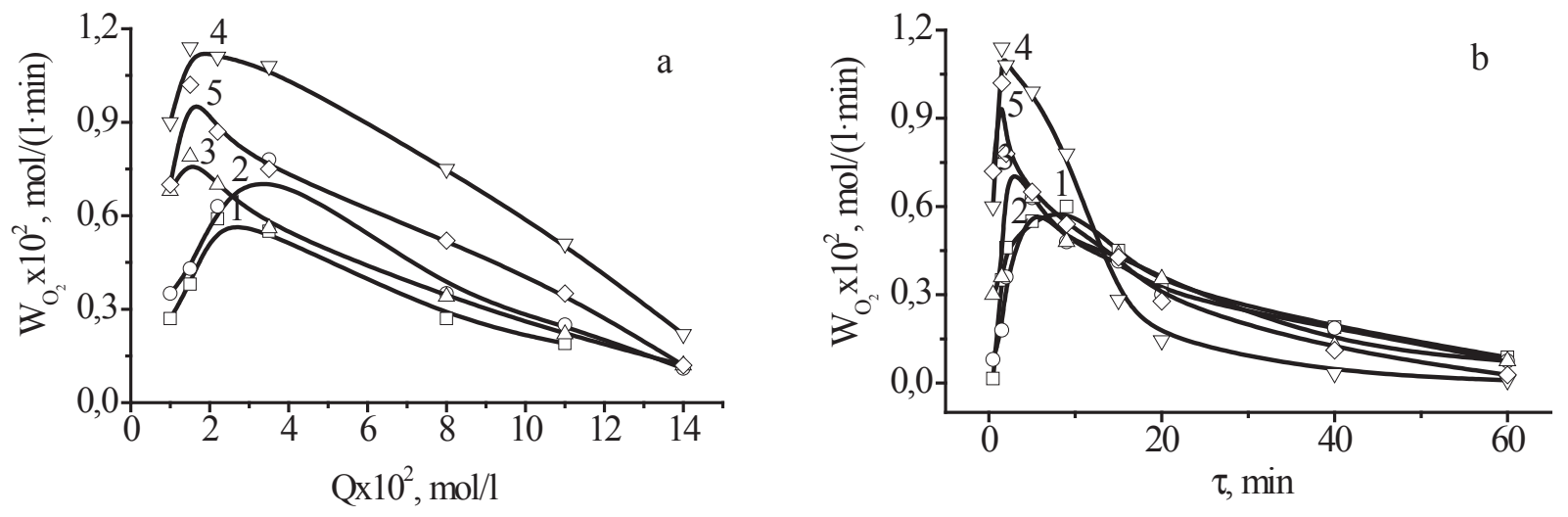

Conditions of reaction, mol/l: $\left[\mathrm{CuCl}_{2}\right]$ 0,57; $\left[\mathrm{NaH}_{2} \mathrm{PO}_{2}\right]$ 0,34; $\left[\mathrm{H}_{2} \mathrm{O}\right] 28-50 ; 60^{\circ} \mathrm{C} ; \mathrm{P}_{\mathrm{O} 2}$ of $1 \mathrm{~atm} ;[\mathrm{FA}]: 1-0,03 ; 2-0,05$; $3-0,08 ; 4-0,11 ; 5-0,14$.

Figure - Conversion (a) and kinetic (b) curves of $\mathrm{NaH}_{2} \mathrm{PO}_{2}$ oxidation by oxygen in the water medium in the presence of copper(II) chloride and humic (fulvo-) acid extracted from brown coal of domestic deposit Kiyakty

On the other hand the increase of solution acidity slows down reaction of water deprotonation, being one of the most important stages of process of an oxidative hydroxylation. The increase in temperature in an interval $50-70^{\circ} \mathrm{C}$ positively affects on reaction velocity and yield of a target product (table).

\section{Conclusion}

Thus, the promotive influence of an added humic (fulvo-) acid extracted from coal of the Kiyakty field, on velocity of an oxidative hydroxylation of $\mathrm{NaH}_{2} \mathrm{PO}_{2}$ in the presence of copper(II) chloride is revealed. The optimum conditions of reaction course of sodium hypophosphite oxidation with formation of phosphorus acids are: temperature $60^{\circ} \mathrm{C} ; \mathrm{P}_{\mathrm{O} 2} 1$ atm; $\mathrm{H}_{2} \mathrm{O}=60$ vol. \%; $\mathrm{FA}=30$ about. \%; $\mathrm{CuCl}_{2} /$ $\mathrm{NaH}_{2} \mathrm{PO}_{2}=1,7 ; \mathrm{FA} / \mathrm{NaH}_{2} \mathrm{PO}_{2}=1: 10$.

\section{Acknowledgements}

The authors gratefully acknowledge the support of Ministry of Education and Science of Republic of Kazakhstan (№ 505 grant, on a priority 5.1. "Basic researches in the field of natural sciences», according to the program "The development of scientific bases of processing of combustible minerals and obtaining of new materials»).

\section{References}

1 Dorfman Ya.A., Aleshkovf M.M., Polimbetova G.S., Levina L.V., Petrova T.V., Abdreimova R.R., Doroshkevich D.M. New reactions of oxidative P-O, P-N, P-C phosphorylation of organic compounds by phosphorus and phosphides in the pres- 
ence of metal complexes of // Usp. Chim. - 1993. - T. 62, № 9. - P. 928-948.

2 Ibraimova Zh.U., Polimbetova G.S., Aleshkova M.M. Oxydative alkoxylation of zinc phosphide in alcoholic solutions of copper(II) of and iron (III) chlorides // Izv. NAN RK. Ser. Chim. - 2005. - № 2. - P. 3-9.

3 Polimbetovas G.S., Zhumadilov A.K., Borangaziyeva A.K., Stanbekova B.L. Oxydative alkoxylation of phosphine in butanolic solutions of FeCl3-I2 // Izv. NAN RK. Ser. Chim. - 2004. № 2. - P. 58-65.

4 Abdreimova R.R., Akbaeva D.N., Polimbetova G.S., Caminade A. - M., Majoral J. - P. Chlorine free synthesis of organophosphorus compounds based on the functionalization of white phosphorus (P4) // Phosphorus, Sulfur and Silicon. - 2000. Vol. 156. - P. 239-254.

5 Abdreimova R.R., Akbaeva D.N., Faizova F. Kh., Polimbetova G.S., Aibasova S. M., Borangazieva A.K., Aliev M.B. Catalitic synthesis of the esters of phosphorus acids from white phosphorus and aliphatic or aromatic alcohols // J. Eurasian Chem. Tech. - 2002. - Vol. 4, № 1. - P. 11-17.

6 Malyshev V.P. The method of experiment planning. - Alma-Ata: Science, 1981. - 116 p.

7 Zlobina E.V., Dolgova N.D. Tasks and methodical instructions for laboratory researches in analytical chemistry. Ed.-method. Handbook. - Almaty: Kazakh university. -2010 . -114 p.

Ж.К. Қаирбеков, Д.Н. Ақбаева, Ж.Т. Ешова, М.А. Бажанова

Гумин (фульво-) қышқылымен модифицирленген мыс(II) хлориді қатысында натрий гипофосфатын тотықтыра гидроксилирлеудің кинетикасы

Жұмсақ жағдайларда $\left(50-70{ }^{\circ} \mathrm{C}, \mathrm{P}_{\mathrm{O} 2}=1\right.$ атм) сулы-толуолды ерітінділерде натрий гипофосфиті гумин (фульво-) қышқылдарымен модифицирленген мыс(II) хлориді қатысында фосфор қышқылын түзе оттекпен тиімді тотығатыны айқындалды. Гумин (фульво-) қышқылы Қияқты кен орны қоңыр көмірінен бөлініп алынды. Гумин қышқылдарын бөліп алудың қолайлы әдістері тәжірибені ықтималды болжау әдісі қолданылып жүргізілді. Волюмометрия, редокс-потенциометрия, кинетика, титрлеу әдістерімен кинетика, аралық және соңғы өнімдер зерттеліп, сулы ерітінділерде $\mathrm{NaH}_{2} \mathrm{PO}_{2}$ оттекпен тотықтырудың жаңа катализдік рекцияларының қолайлы жағдайлары, кинетикалық анықталды.

Tүйін сөздер: натрий гипофосфиті, тотызу, оттек, гумин (фульво-) қъышқылы, гидроксилдеу, фосфорлау қышиқылы, кинетика, ққолайлы жавдайлар.

Ж.К. Каирбеков, Д.Н. Акбаева, Ж.Т. Ешова, М.А. Бажанова

Кинетика окислительного гидроксилирования гипофосфита натрия в присутствии хлорида меди(II), модифицированного гуминовой (фульво-) кислотой

Установлено, что в мягких условиях $\left(50-70^{\circ} \mathrm{C}, \mathrm{P}_{\mathrm{O} 2}=1\right.$ атм) гипофосфит натрия эффективно окисляется кислородом в водных растворах хлорида меди(II) с преимущественным образованием фосфористой кислоты. Гуминовая (фульво-) кислота была выделена из бурого угля отечественного месторождения Киякты. Для определения оптимальных параметров извлечения гуминовых кислот проведены лабораторные опыты с использованием метода вероятностно-детерминированного планирования эксперимента. Методами кинетики, волюмометрии, редокс-потенциометрии и титриметрии исследованы кинетика, промежуточные и конечные продукты, определены оптимальные условия новой каталитической реакции окисления $\mathrm{NaH}_{2} \mathrm{PO}_{2}$ кислородом в водных средах.

Ключевые слова: гипофосфит натрия, окисление, кислород, гуминовая (фульво-) кислота, гидроксилирование, фосфористая кислота, кинетика, оптимальные условия. 